\title{
Nano-SIMS Analysis of Mg, Sr, Ba and U in Natural Calcium Carbonate
}

\author{
Yuji Sano, ${ }^{* \dagger}$ Kotaro Shirai, $*$ Naoto Takahata,* Takafumi Hirata,** and Neil C. STURChIO*** \\ * Ocean Research Institute, The University of Tokyo, Nakanoku, Tokyo 164-8639, Japan \\ **Department of Earth and Planetary Sciences, Tokyo Institute of Technology, Meguroku, Tokyo 152-8551, Japan \\ ***Department of Earth and Environmental Sciences, University of Illinois at Chicago, Chicago, \\ Illinois 60607-7059, USA
}

\begin{abstract}
Concentrations of minor ( $\mathrm{Mg}$ and $\mathrm{Sr})$ and trace $(\mathrm{Ba}$ and $\mathrm{U})$ elements in four natural calcium carbonate samples were first analyzed by inductively coupled plasma mass spectrometry (ICP-MS) after chemical dissolution and calibrated against a standard dolomite. Their homogeneities were checked by in situ laser ablation (LA) ICP-MS with $10-20$ spots. The carbonate samples were measured by using a high lateral resolution secondary ion mass spectrometer (Nano-SIMS NS50). A $\sim 4 \mathrm{nA} \mathrm{O}^{-}$primary beam was used to sputter a 5-6- $\mu \mathrm{m}$ diameter crater on the sample surface, and secondary positive ions were extracted for mass analysis using an accelerating voltage of $8 \mathrm{kV}$ and a Mattauch-Herzog geometry. A multi-collector system was adjusted to detect ${ }^{26} \mathrm{Mg}^{+},{ }^{43} \mathrm{Ca}^{+},{ }^{88} \mathrm{Sr}^{+},{ }^{138} \mathrm{Ba}^{+},{ }^{238} \mathrm{U}^{16} \mathrm{O}^{+}$and ${ }^{238} \mathrm{U}^{16} \mathrm{O}_{2}{ }^{+}$ions at the same time. A resolving power of 2500 - 5000 at $10 \%$ peak height was attained by an entrance slit set at $40 \mu \mathrm{m}$, and each exit slit at 50 $\mu \mathrm{m}$ with adequate flat-topped peaks. The observed ${ }^{26} \mathrm{Mg} /{ }^{43} \mathrm{Ca},{ }^{88} \mathrm{Sr} /{ }^{43} \mathrm{Ca},{ }^{138} \mathrm{Ba} /{ }^{43} \mathrm{Ca}$ and ${ }^{238} \mathrm{U}^{16} \mathrm{O}_{2} /{ }^{43} \mathrm{Ca}$ ratios agreed well with those measured by LA-ICP-MS. Foraminifera shells were analyzed at $5-6 \mu \mathrm{m}$ scale by Nano-SIMS. There was a large variation of the $\mathrm{Mg} / \mathrm{Ca}$ ratios, up to $\pm 38 \%$, even in a single fragment of the shell, suggesting that although the ratios provide a useful paleoceanographic proxy at bulk scale, they may reflect a more complex pattern at $<10 \mu \mathrm{m}$ scale.
\end{abstract}

(Received March 23, 2005; Accepted July 26, 2005)

\section{Introduction}

In paleoclimate studies, valuable information, such as ancient ocean temperatures ${ }^{1-3}$ and past alkalinity distributions, ${ }^{4}$ can be derived from the study of minor $(\mathrm{Mg}$ and $\mathrm{Sr})$ and trace $(\mathrm{Ba}$ and $\mathrm{U})$ element concentrations in marine calcium carbonates. These effects are attributable to the fact that $\mathrm{Mg}, \mathrm{Sr}$ and $\mathrm{Ba}$ are members of Group II in the periodic table, and all have very similar chemical and physical properties, including a stable $2+$ oxidation state. However, they do not behave identically in nature, and their differences in behavior have significant implications in geochemistry. For example, laboratory experiments have shown that the partition coefficient of $\mathrm{Mg}^{2+}$ into inorganic calcite correlates strongly with temperature. ${ }^{5}$ Recent studies have revealed that the U/Ca ratios in corals could provide a temperature proxy comparable in accuracy to the $\mathrm{Sr} / \mathrm{Ca}$ ratios. ${ }^{6}$ The mechanism may be ascribed to a recent study ${ }^{7}$ showing that the uranyl ion $\left(\mathrm{UO}_{2}{ }^{2+}\right)$ substitutes easily for $\mathrm{Ca}^{2+}$ in aragonite. In addition, the $\mathrm{Ba} / \mathrm{Ca}$ ratio of biogenic carbonate has been used to reconstruct past alkalinity distributions in oceans. ${ }^{4}$

There are several analytical methods that can be applied to measuring these elements at the $\sim 50 \mu \mathrm{m}$ scale in calcium carbonate, such as laser ablation inductively coupled plasma mass spectrometry (LA-ICP-MS), secondary ion mass spectrometry (SIMS) and electron microprobe (EMP). Among

$\dagger$ To whom correspondence should be addressed.

E-mail: ysano@ori.u-tokyo.ac.jp them, the LA-ICP-MS method $^{8}$ has a number of advantages, such as being easy to operate, less expensive and having a smaller matrix effect than the SIMS method. ${ }^{9}$ However, LAICP-MS consumes more sample (has worse depth resolution) and it is difficult to reduce the probe spot to $<10 \mu \mathrm{m}$ to achieve greater sensitivity. On the other hand, the advantages of the EMP method ${ }^{10}$ are its relatively low cost and excellent spatial resolution (spot size $\sim 3 \mu \mathrm{m}$ ) compared with the SIMS method, while the major drawback of the EMP is its relatively low sensitivity, whereby it is impossible to detect trace elements at the several $10 \mathrm{~s} \mu \mathrm{mol} / \mathrm{mol}$ level.

The most powerful tool for precise trace-element analysis of calcium carbonate is the SIMS method with its significant depth resolution. ${ }^{9}$ Recently, a Nano-SIMS NS50 ion microprobe with unparalleled lateral resolution up to $0.05 \mu \mathrm{m}$ has been developed by Cameca ${ }^{11}$ and mostly applied to the field of cosmochemistry, ${ }^{12,13}$ with few geochemical applications thus far. ${ }^{14,15}$ It is desirable to apply this new ion microprobe to the analysis of terrestrial samples with its high lateral resolution.

In this work, minor ( $\mathrm{Mg}$ and $\mathrm{Sr}$ ) and trace (Ba and $\mathrm{U})$ element analysis of natural calcium carbonate was carried out by using a Nano-SIMS NS50 instrument. Experimental details of the ion microprobe measurements at spot size of 5-6 $\mathrm{m}$ are given. We assessed the accuracy and precision of the analyses as compared with those determined by ICP-MS after chemical dissolution, and also those determined by LA-ICP-MS on the same samples measured by Nano-SIMS. We then applied this method to foraminifera, which are tiny single-celled marine organisms that construct calcium carbonate shells. 


\section{Experimental}

\section{Samples}

Five natural calcium carbonate samples were prepared. They were named JDo-1, LAS20, NBS19, TN2349 and SPA4. JDo-1 is a dolomite standard collected from Kuzuu-machi, Tochigi Prefecture, central Japan and distributed by the Geological Survey of Japan ${ }^{16}$ for a reference of sedimentary rock. LAS20 and SPA4 are both U-rich calcite with thick aragonite rims extracted from a 13700 year old speleothem deposit in the Vinschgau Valley of northernmost Italy. ${ }^{17}$ NBS19 is a calcite standard derived from a limestone of unknown origin and distributed by the US National Bureau of Standards for carbon isotope measurements. ${ }^{18}$ TN2349 is a 35 million year old calcite from a Mississippi Valley-type zinc ore deposit. ${ }^{19}$ Planktonic foraminiferal shells were collected by a box core in the western equatorial Pacific by the KH92-1 cruise of the Research Vessel, Hakuho Maru of the Ocean Research Institute, the University of Tokyo. The species was identified as Globigerinoides sacculifer, which is generally abundant in tropical water masses. ${ }^{20}$

\section{ICP-MS solution analysis}

Calcium carbonate samples were crushed and homogenized, and then aliquots weighing about $5 \mathrm{mg}$ were dissolved by $\mathrm{HNO}_{3}$ and diluted so that the $\mathrm{Ca}$ concentrations were $2.0 \pm 0.3 \mathrm{ppm}$. The abundances of $\mathrm{Mg}, \mathrm{Sr}, \mathrm{Ba}$ and $\mathrm{U}$ were determined by ICPMS (ThermoElectron VG PlasmaQuad 2) installed at Department of Earth and Planetary Sciences, Tokyo Institute of Technology. It was confirmed that the isotopic compositions of $\mathrm{Mg}, \mathrm{Ca}, \mathrm{Sr}$ and $\mathrm{Ba}$ agreed with those of reference values. In actual analysis, the quadrupole mass spectrometer was cyclically peak-stepped through a series of mass numbers, (26, $43,88,138$ and 238) to measure the ${ }^{26} \mathrm{Mg},{ }^{43} \mathrm{Ca},{ }^{88} \mathrm{Sr},{ }^{138} \mathrm{Ba}$ and ${ }^{238} \mathrm{U}$ intensities by using an ion counting detector with $10 \mathrm{~s}$ integrations. The observed ${ }^{26} \mathrm{Mg} /{ }^{43} \mathrm{Ca},{ }^{88} \mathrm{Sr} /{ }^{43} \mathrm{Ca},{ }^{138} \mathrm{Ba} /{ }^{43} \mathrm{Ca}$ and ${ }^{238} \mathrm{U} /{ }^{43} \mathrm{Ca}$ ratios of four samples (LAS20, NBS19, TN2349 and SPA4) were calibrated against those of JDo-1 with certified abundances after subtracting blanks measured on deionized water prepared by using Milli-Q SP ICPMS Spec.

\section{Laser ablation ICP-MS analysis}

Calcium carbonate grains were cast into an epoxy resin disc together with two chips of NIST standard silicate glasses (SRM610 and 612). The samples were polished until the midsections of the chips were exposed. Final polishing was made with $0.25 \mathrm{~mm}$ diamond paste. For elemental analysis using LAICP-MS, the laser ablation sample introduction technique was applied in this study. ${ }^{21}$ The laser ablation system used in this study was a MicroLas Laser Ablation System (Gottingen, Germany) GeoLas 200CQ. ${ }^{22}$ This system utilizes a Lambda Physik (Gottingen, Germany) COMPex 102 ArF excimer laser operating at $193 \mathrm{~nm}$. He gas instead of Ar gas was used as a carrier gas, which improved the sample transport efficiency from the sample cell to ICP, and reduced the sample desorption around the ablation pit. ${ }^{23}$ The resulting instrumental sensitivity was about $>400 \mathrm{~Hz} / \mu \mathrm{g} \mathrm{g}^{-1}$ for the analyses, when an ablation pit size of $16 \mu \mathrm{m}$, and a laser emission power of $2 \mathrm{~mJ}$ with repetition rate of $5 \mathrm{~Hz}$ were applied. The typical drilling rate observed here was $0.5 \mu \mathrm{m} / \mathrm{s}$, and therefore, the resulting depth of the ablation pit was $5-8 \mu \mathrm{m}$ after the analysis sequence (15 s) under the conditions, such as the laser power and repetition rate, employed in this study. In order to minimize the elemental fractionation and to improve the repeatability in the elemental

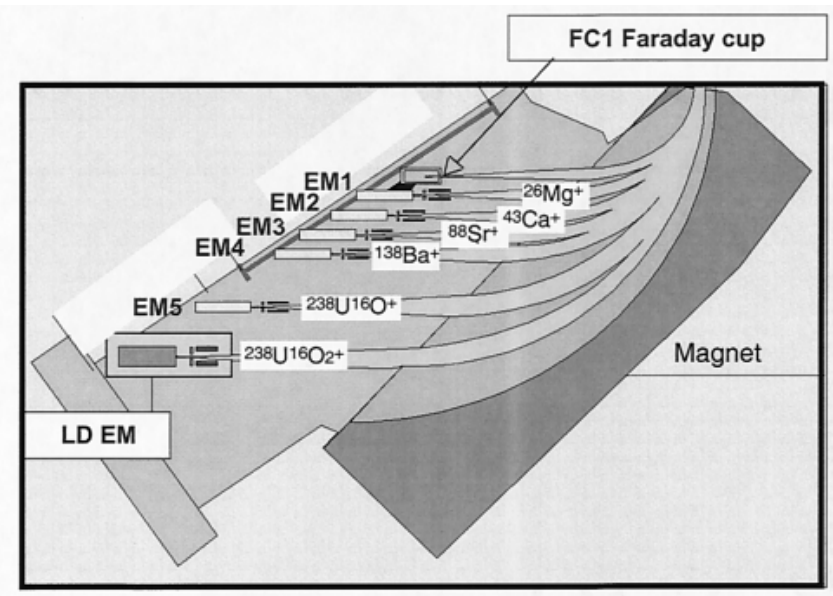

Fig. 1 Configuration of the multi-collector system of Nano-SIMS The ion counting detectors, EM\#1 - EM\#4 are movable on a trolley, while EM\#5 and LD are fixed. It is possible to detect ${ }^{26} \mathrm{Mg}^{+},{ }^{43} \mathrm{Ca}^{+}$ ${ }^{88} \mathrm{Sr}^{+},{ }^{138} \mathrm{Ba}^{+},{ }^{238} \mathrm{U}^{16} \mathrm{O}^{+}$and ${ }^{238} \mathrm{U}^{16} \mathrm{O}_{2}{ }^{+}$ions at the same time. Deflectors are located immediately before each exit slit.

ratio measurement achieved by the LA-ICPMS, a stabilizer device was applied. ${ }^{24}$ The stabilizer device acted as a particle filter, which could minimize the introduction of large aerosol particles into the ICP, which could cause a spiky and unstable signal intensity. The resulting ablation pit size was $18 \mu \mathrm{m}$, obtained through data integration $(20 \mathrm{~s} / \mathrm{spot})$. The experimental settings of the ICP-MS were the same as those of solution analysis. The observed data were again calibrated against those of JDo-1.

\section{Nano-SIMS}

Planktonic foraminiferal shells were cast into an epoxy resin disc together with a grain of LAS20 calcite and two chips of NIST standard silicate glasses (SRM610 and 612). The samples were polished until the mid-sections of the shells and chips were exposed. Final polishing was made with $0.25 \mu \mathrm{m}$ diamond paste to provide a flat surface for the sputtering of secondary ions, and the disc surface was carbon-coated. Images of the sample were determined by an electron microprobe (EMP) to locate inclusion-free homogeneous regions suitable for analysis. It was then slightly polished again to remove the carbon coat and damaged layer of the EMP. Prior to analysis, the foraminifera mount as well as the carbonate mount were cleaned with petroleum spirits, detergent and pure water to reduce the surface contaminants, and then gold coated to dissipate any charge during the analysis.

There are two crucial advantages of Nano-SIMS over any conventional SIMS. First, the co-axial mode of primary and secondary beams gives a short working distance of the probe forming lens/extraction system, resulting in a smaller spot size for a provided beam current. Second, the multi-collector system with a Mattauch-Herzog geometry covers a wider range of mass numbers (Fig. 1). In the present study, we could detect ${ }^{26} \mathrm{Mg}$ (by an ion-counting detector, called EM\#1, which could move on the trolley and be set at a radius $(R)$ of $170.9 \mathrm{~mm}),{ }^{43} \mathrm{Ca}$ (EM\#2; set at $R=219.5 \mathrm{~mm}),{ }^{88} \mathrm{Sr}(\mathrm{EM \# 3}$; set at $R=313.9$ $\mathrm{mm}),{ }^{138} \mathrm{Ba}($ EM\#4; set at $R=394.3 \mathrm{~mm}),{ }^{238} \mathrm{U}^{16} \mathrm{O}$ (EM\#5; position fixed at $R=533.2 \mathrm{~mm}$ ) and ${ }^{238} \mathrm{U}^{16} \mathrm{O}_{2}$ (LD; fixed at $R=$ $549.8 \mathrm{~mm}$ ) at the same time under a static magnetic field. The entrance and exit slits (EM\#1 - \#5 and LD) were set to about 40 $\mu \mathrm{m}$ and $50 \mu \mathrm{m}$ each, respectively.

The samples were evacuated in an air lock overnight and 

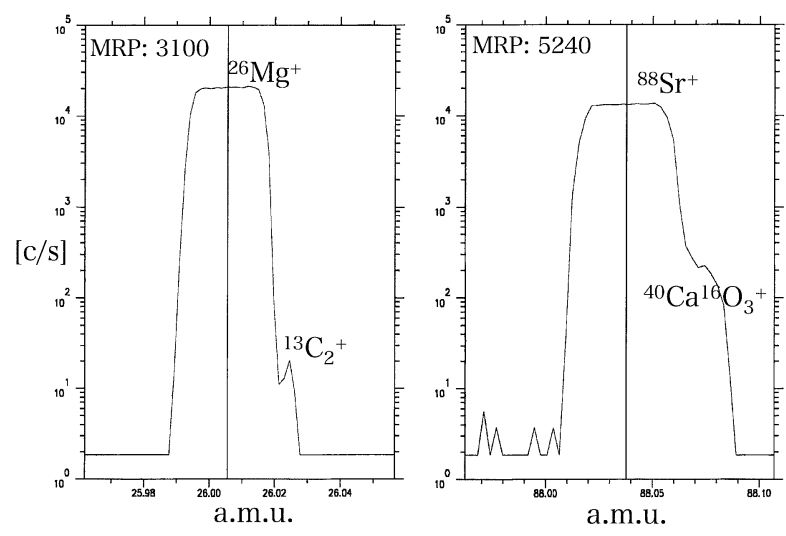

Fig. 2 Mass spectra around the ${ }^{26} \mathrm{Mg}^{+}$(a) and ${ }^{88} \mathrm{Sr}^{+}$(b) peaks of natural calcium carbonate, LAS20. The spectra were obtained by deflector voltage scanning under a static magnetic field. The mass resolving power is variable dependent on the detector position.

introduced into a sample stage in the ion source chamber of a Nano-SIMS installed at the Ocean Research Institute, the University of Tokyo. A mass-filtered $\sim 4 \mathrm{nA}{ }^{16} \mathrm{O}^{-}$primary beam was used to sputter a 5-6- $\mu \mathrm{m}$ diameter crater on the sample surface, and secondary positive ions were extracted for mass analysis using an accelerating voltage of $8 \mathrm{kV}$. The focusing conditions of ions may have been slightly different from one detector to the other, depending on the trolley position (Fig. 1), which would sometime lead to a different mass resolving power under the static magnetic field. Figure 2 shows the mass spectra around (a) ${ }^{26} \mathrm{Mg}^{+}$and (b) ${ }^{88} \mathrm{Sr}^{+}$peaks of LAS20 calcite obtained by a deflector located immediately before the exit slit with a voltage scan. It is noted that the ion source condition and magnetic field were identical. A resolving power of 3100 was attained at $10 \%$ peak height of ${ }^{26} \mathrm{Mg}^{+}(R=170.9 \mathrm{~mm})$, where the interference of ${ }^{13} \mathrm{C}_{2}{ }^{+}$was negligibly small, while the resolving power of 5240 was taken at ${ }^{88} \mathrm{Sr}^{+}(R=313.9 \mathrm{~mm})$, which showed a small side peak of ${ }^{40} \mathrm{Ca}^{16} \mathrm{O}_{3}{ }^{+}$. Before the actual analysis, the sample surface was rastered for $3 \mathrm{~min}$ in order to clean off any possible contaminants. It was checked that the isotopic compositions of $\mathrm{Mg}, \mathrm{Ca}$ and $\mathrm{Sr}$ agreed with those of the reference values by magnet scanning, even though that of $\mathrm{Ba}$ in TN2349 was discrepant from the reference. We measured the ${ }^{26} \mathrm{Mg},{ }^{43} \mathrm{Ca},{ }^{88} \mathrm{Sr},{ }^{138} \mathrm{Ba}$ and ${ }^{238} \mathrm{U}^{16} \mathrm{O}$ and ${ }^{238} \mathrm{U}^{16} \mathrm{O}_{2}$ intensities of the samples by using ion-counting detectors (EM\#1 - 5 and LD) with $10 \mathrm{~s}$ integrations under a static magnetic field. It took about $10 \mathrm{~min}$ to complete a single analysis, including the surface rastering and 50 ratio measurements. The observed data of four samples (LAS20, NBS19, TN2349 and SPA4) were calibrated against those of JDo- 1 . The ${ }^{26} \mathrm{Mg} /{ }^{43} \mathrm{Ca},{ }^{88} \mathrm{Sr} /{ }^{43} \mathrm{Ca}$, ${ }^{138} \mathrm{Ba} /{ }^{43} \mathrm{Ca}$ and ${ }^{238} \mathrm{U}^{16} \mathrm{O}_{2} /{ }^{43} \mathrm{Ca}$ ratios of NIST standard silicate glasses (SRM610 and 612) were also determined in the same manner as calcium carbonate samples.

\section{Results and Discussion}

\section{Calcium carbonate}

Table 1 lists the $\mathrm{Mg} / \mathrm{Ca}, \mathrm{Sr} / \mathrm{Ca}, \mathrm{Ba} / \mathrm{Ca}$ and $\mathrm{U} / \mathrm{Ca}$ ratios of four natural calcium carbonate samples measured by ICP-MS after chemical dissolution. The errors are one sigma, estimated by the reproducibility of 10 measurements as well as those of a standard sample (JDo-1) combined in quadrature. The precision is less than $5 \%$ for the minor elements and $10 \%$ for the trace
Table 1 Minor and trace elements in calcium carbonate samples measured by ICP-MS after chemical dissolution

\begin{tabular}{lcccc}
\hline Sample & $\begin{array}{c}\mathrm{Mg} / \mathrm{Ca} \\
\mathrm{mmol} / \mathrm{mol}\end{array}$ & $\begin{array}{c}\mathrm{Sr} / \mathrm{Ca} \\
\mathrm{mmol} / \mathrm{mol}\end{array}$ & $\begin{array}{c}\mathrm{Ba} / \mathrm{Ca} \\
\mu \mathrm{mol} / \mathrm{mol}\end{array}$ & $\begin{array}{c}\mathrm{U} / \mathrm{Ca} \\
\mu \mathrm{mol} / \mathrm{mol}\end{array}$ \\
\hline JDo-1 $^{\mathrm{a}}$ & 757 & 0.219 & 7.38 & 0.595 \\
LAS20 & $31.10 \pm 0.95$ & $0.595 \pm 0.009$ & $18.42 \pm 0.99$ & $119.3 \pm 7.4$ \\
NBS19 & $13.04 \pm 0.64$ & $0.199 \pm 0.006$ & $2.41 \pm 0.24$ & $0.34 \pm 0.05$ \\
TN2349 & $3.62 \pm 0.15$ & $0.101 \pm 0.002$ & - & $10.30 \pm 0.67$ \\
SPA4 & $3.20 \pm 0.16$ & $1.437 \pm 0.023$ & $11.44 \pm 0.47$ & $74.74 \pm 4.59$ \\
\hline
\end{tabular}

a. From GSJ Geochemical Reference samples DataBase (http://www. aist.go.jp/RIODB/geostand)

Errors are one sigma.

Table 2 Minor and trace elements in calcium carbonate samples measured by in situ LA-ICP-MS

\begin{tabular}{lcccc}
\hline Sample & $\begin{array}{c}\mathrm{Mg} / \mathrm{Ca} \\
\mathrm{mmol} / \mathrm{mol}\end{array}$ & $\begin{array}{c}\mathrm{Sr} / \mathrm{Ca} \\
\mathrm{mmol} / \mathrm{mol}\end{array}$ & $\begin{array}{c}\mathrm{Ba} / \mathrm{Ca} \\
\mu \mathrm{mol} / \mathrm{mol}\end{array}$ & $\begin{array}{c}\mathrm{U} / \mathrm{Ca} \\
\mu \mathrm{mol} / \mathrm{mol}\end{array}$ \\
\hline JDo-1 $^{\mathrm{a}}$ & 757 & 0.219 & 7.38 & 0.595 \\
LAS20 & $28.70 \pm 1.20$ & $0.580 \pm 0.024$ & $18.16 \pm 1.08$ & $121.40 \pm 11.90$ \\
NBS19 & $14.05 \pm 1.16$ & $0.176 \pm 0.043$ & $2.03 \pm 0.63$ & - \\
TN2349 & $3.66 \pm 0.29$ & $0.089 \pm 0.025$ & $0.17 \pm 0.10$ & $14.38 \pm 3.10$ \\
SPA4 & $2.38 \pm 0.23$ & $1.238 \pm 0.300$ & $11.53 \pm 3.29$ & $78.39 \pm 21.59$ \\
\hline
\end{tabular}

a. From GSJ Geochemical Reference samples DataBase (http://www. aist.go.jp/RIODB/geostand)

Errors are one sigma.

elements, except for the U/Ca ratio of NBS19. The Ba/Ca ratio of TN2349 was not obtained because of its lower abundance than the detection limit.

Table 2 lists the $\mathrm{Mg} / \mathrm{Ca}, \mathrm{Sr} / \mathrm{Ca}, \mathrm{Ba} / \mathrm{Ca}$ and $\mathrm{U} / \mathrm{Ca}$ ratios of four natural calcium carbonate samples measured by LA-ICP-MS. Analysis spots with $30 \mu \mathrm{m}$ diameter were randomly selected on the surface. The errors are one sigma, estimated by the reproducibility of $10-20$ spot measurements as well as those of a standard sample (JDo-1) combined in quadrature. The precision is $5 \%-30 \%$, except for the $\mathrm{Ba} / \mathrm{Ca}$ ratio of $\mathrm{TN} 2349$, and generally larger than those of the solution analysis. The U/Ca ratio of NBS19 was not obtained because of the low U abundance.

Taking into account the error, the observed $\mathrm{Mg} / \mathrm{Ca}, \mathrm{Sr} / \mathrm{Ca}$, $\mathrm{Ba} / \mathrm{Ca}$ and $\mathrm{U} / \mathrm{Ca}$ ratios measured by solution analysis agree well with those measured by LA-ICP-MS, suggesting that the accuracy of the measurement is acceptable. The relatively large errors of the LA-ICP-MS method may be attributable to either the lateral heterogeneity of the samples and/or smaller intensities of the measured ions. For example, the U intensity of NBS19 was about $30 \mathrm{cps}$, which was equivalent to background level, while that of SPA4 was large with a value of $43000-69000 \mathrm{cps}$. In the latter case, the sample heterogeneity is dominant reason of the error. Among the carbonate samples, LA-ICP-MS analysis of LAS20 shows the smallest errors, 5\% for minor elements and 5-10\% for trace elements. Therefore, we selected LAS20 as a standard for foraminifera measurements.

Table 3 lists the ${ }^{26} \mathrm{Mg} /{ }^{43} \mathrm{Ca},{ }^{88} \mathrm{Sr} /{ }^{43} \mathrm{Ca},{ }^{138} \mathrm{Ba} /{ }^{43} \mathrm{Ca}$ and ${ }^{238} \mathrm{U}^{16} \mathrm{O}_{2} /{ }^{43} \mathrm{Ca}$ ratios of four natural calcium carbonate samples measured by Nano-SIMS. Analysis spots with 5-6 $\mu \mathrm{m}$ diameter were selected on the surface of the samples so as to avoid those already measured by LA-ICP-MS. The errors are one sigma, estimated by the reproducibility of 10-20 spot measurements as well as those of a standard sample (JDo-1) 
Table 3 Minor and trace elements in calcium carbonate samples measured by Nano-SIMS

\begin{tabular}{lccccc}
\hline Sample & ${ }^{26} \mathrm{Mg}^{+/ 43} \mathrm{Ca}^{+}(\times 1)$ & ${ }^{88} \mathrm{Sr}^{+}{ }^{43} \mathrm{Ca}^{+}(\times 1)$ & ${ }^{138} \mathrm{Ba}^{+}{ }^{43} \mathrm{Ca}^{+}(\times 0.01)$ & ${ }^{238} \mathrm{U}^{16} \mathrm{O}_{2}{ }^{+/ 43} \mathrm{Ca}^{+}(\times 0.01)$ & Corrected ${ }^{138} \mathrm{Ba} /{ }^{43} \mathrm{Ca}(\times 0.01)$ \\
\hline LAS20 & $0.980 \pm 0.051$ & $0.679 \pm 0.033$ & $1.030 \pm 0.107$ & $0.726 \pm 0.097$ & 0.834 \\
NBS19 & $0.463 \pm 0.021$ & $0.264 \pm 0.012$ & $0.220 \pm 0.022$ & $0.0019 \pm 0.0008$ & 0.127 \\
TN2349 & $0.122 \pm 0.012$ & $0.131 \pm 0.013$ & $0.035 \pm 0.003$ & $0.121 \pm 0.044$ & 0.011 \\
SPA4 & $0.100 \pm 0.007$ & $1.555 \pm 0.112$ & $0.660 \pm 0.050$ & $0.553 \pm 0.151$ & 0.640 \\
\hline
\end{tabular}

Errors are one sigma.
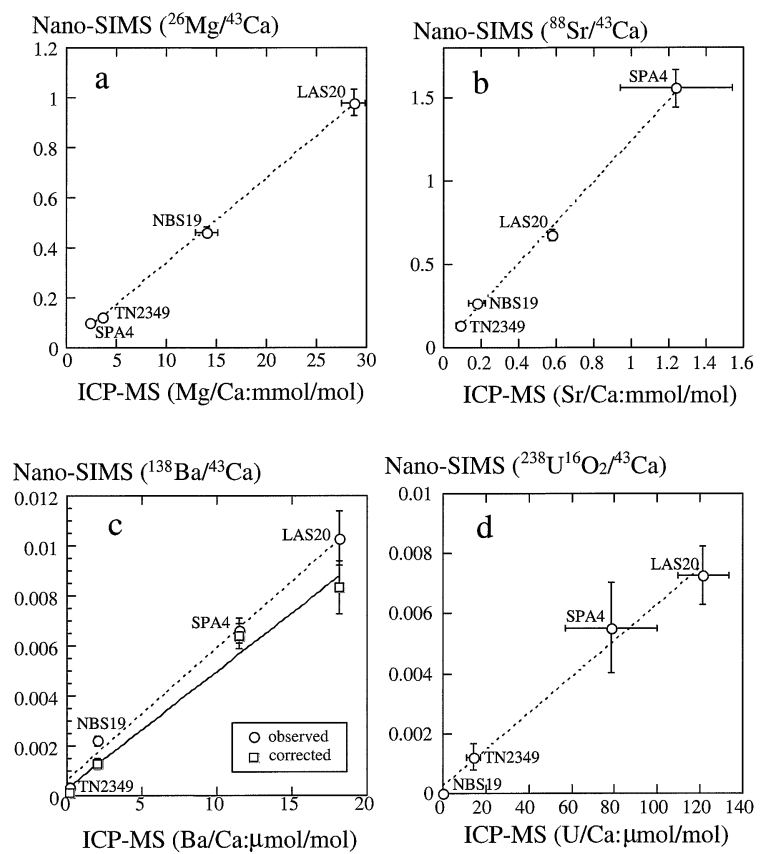

Fig. 3 Comparisons between LA-ICP-MS and Nano-SIMS analysis of four natural calcium carbonates. They are $\mathrm{Mg} / \mathrm{Ca}$ (3a), $\mathrm{Sr} / \mathrm{Ca}(3 b)$, $\mathrm{Ba} / \mathrm{Ca}(3 \mathrm{c})$ and $\mathrm{U} / \mathrm{Ca}(3 \mathrm{~d})$. The U/Ca ratio of NBS19 is referred from solution analysis in Table 1. Errors are portrayed at the one-sigma level. Generally, Nano-SIMS data agree with those of LA-ICP-MS.

combined in quadrature. The precision is $5 \%-10 \%$, except for the ${ }^{238} \mathrm{U}^{16} \mathrm{O}_{2} /{ }^{43} \mathrm{Ca}$ ratios. It is documented that $\mathrm{Pb}$ is emitted almost entirely as $\mathrm{Pb}^{+}$while formed $\mathrm{UO}_{2}^{+}: \mathrm{UO}^{+}: \mathrm{U}^{+}$are 10:10:1 on monazite $\left[(\mathrm{Ce}, \mathrm{La}, \mathrm{Nd}, \mathrm{Th}) \mathrm{PO}_{4}\right]$ sputtered by a ${ }^{16} \mathrm{O}^{-}$primary beam of Nano-SIMS. ${ }^{15}$ In the present case, the formed $\mathrm{UO}_{2}{ }^{+}: \mathrm{UO}^{+}: \mathrm{U}^{+}$in calcium carbonates are 50:7:1, which implies that metal ions of $U$ are negligibly small. Therefore, we take the ${ }^{238} \mathrm{U}^{16} \mathrm{O}_{2}^{+} / 43 \mathrm{Ca}^{+}$ratios instead of the simple ${ }^{238} \mathrm{U}^{+/ 43} \mathrm{Ca}^{+}$ratios. We speculate that the relatively high $\mathrm{UO}_{2}{ }^{+}$yield of LAS-20, compared with monazite, ${ }^{15}$ may reflect the $6+$ oxidation state of $\mathrm{U}$ in LAS $-20,{ }^{25}$ whereas $\mathrm{U}$ in monazite is likely to be present in the 4+ oxidation state.

Figure 3 shows a comparison between LA-ICP-MS and NanoSIMS data of four natural carbonates. The U/Ca ratio of NBS19 is referred from the solution analysis in Table 1 . The errors are portrayed at the one-sigma level. The $\mathrm{Mg} / \mathrm{Ca}$ ratios measured by LA-ICP-MS agree well with those by Nano-SIMS within the experimental error margin (Fig. 3a). A linear-regression analysis of the data gave a slope of $0.03372 \pm 0.00080$ ( 1 sigma) and a Y-intercept of $0.0049 \pm 0.0128$ (1 sigma) with a correlation coefficient of $R=0.9994$, which indicates that the data are analytically indistinguishable. The other minor element ratio, the $\mathrm{Sr} / \mathrm{Ca}$ values, show a similar trend between LA-ICP-
MS and Nano-SIMS. A Y-intercept of $0.0201 \pm 0.0328$ (1 sigma) with $R=0.9985$ implies that the best-fit correlation line would cross the origin of the coordinate axes (Fig. 3b). The $\mathrm{Ba} / \mathrm{Ca}$ ratios measured by LA-ICP-MS are comparable with the Nano-SIMS data. However, the Y-intercept of $0.000642 \pm$ 0.000331 (1 sigma) means that the line barely goes through the coordinate origin (Fig. 3c). The other trace element ratio, the $\mathrm{U} / \mathrm{Ca}$ values of LA-ICP-MS are generally consistent with those of Nano-SIMS, even though the experimental errors are relatively large (Fig 3d). Again, the Y-intercept of $0.000257 \pm$ 0.000360 (1 sigma) shows that both data sets are in agreement. These lines of evidence suggest that the Nano-SIMS measurements at a spot size of 5-6 $\mu \mathrm{m}$ are mostly reliable and accurate with $5 \%-10 \%$ precision, except for the trace element ratios, even though we should take into account the sample homogeneity.

\section{Secondary-ion yields}

Generally, secondary ion yields are required to convert the observed peak intensities into concentrations of elements by using SIMS. If matrix effects are significant, a good matrixmatched calibration standard is required. It is well documented that the sensitivity for $\mathrm{Al}$ relative to $\mathrm{Si}$ differs appreciably in different silicate mineral samples. ${ }^{26}$ There are quite large variations in the secondary ion yields of major elements in olivines and low-Ca pyroxenes. ${ }^{27}$ In order to explain the matrix effect, a bond-breaking model was proposed for the ionization process, ${ }^{28}$ even though the model cannot predict the effect for complex samples quantitatively. Therefore, it is fully accepted that quantitative SIMS analysis requires good calibration standards with approximately similar major chemistry to the samples being analyzed.

We calculated the secondary ion yields of $\mathrm{Mg}, \mathrm{Sr}, \mathrm{Ba}$ and $\mathrm{UO}_{2}$ relative to $\mathrm{Ca}$ based on the observed ratios (Table 3 ) and those determined by LA-ICP-MS (Table 2). Table 4 lists the secondary ion yields in NIST standard silicate glasses (SRM610 and 612) and natural calcium carbonate samples (LAS20, NBS19, TN2349 and SPA4). Simple averages are also added in the lower line. Generally, the relative secondary ion yields do not vary within a single matrix, such as silicate glass and calcium carbonate, while those of $\mathrm{Mg} / \mathrm{Ca}$ and $\mathrm{UO}_{2} / \mathrm{Ca}$ for calcium carbonate are significantly different from those for silicate glass (see average of Table 4). This is consistent with the idea that a good matrix-matched calibration standard is required for quantitative SIMS analysis.

A large variation is observed in the relative yields of $\mathrm{Ba} / \mathrm{Ca}$ of different calcium carbonates, varying from 1.07 to 3.95 (Table 4). This may be attributable to an experimental artifact, and there may be isobaric molecular interference on ${ }^{138} \mathrm{Ba}$. Note that the $\mathrm{Ba}$ isotopic composition of TN2349 did not agree with the reference value, as stated above. We carefully studied the mass spectra around 136 and 137, and finally found that the molecular ion $\mathrm{Ca}_{2} \mathrm{MgO}_{2}$ is a candidate of interference, since the ratio of ${ }^{40} \mathrm{Ca}_{2}{ }^{24} \mathrm{Mg}^{16} \mathrm{O}_{2}$ (136 amu) to ${ }^{40} \mathrm{Ca}_{2}{ }^{25} \mathrm{Mg}^{16} \mathrm{O}_{2}$ (137 amu) is 
Table 4 Relative secondary ion yield of $\mathrm{Mg}, \mathrm{Sr}, \mathrm{Ba}$ and $\mathrm{U}$ in glass and calcium carbonate

\begin{tabular}{lccccc}
\hline & $\mathrm{Mg} / \mathrm{Ca}$ & $\mathrm{Sr} / \mathrm{Ca}$ & $\mathrm{Ba} / \mathrm{Ca}$ & $\mathrm{UO}_{2} / \mathrm{Ca}$ & $\begin{array}{c}\mathrm{Corrected} \\
\mathrm{Ba} / \mathrm{Ca}\end{array}$ \\
\hline $\begin{array}{l}\text { Glass } \\
\text { SRM610 }\end{array}$ & 0.76 & 1.86 & 1.77 & 0.068 & - \\
SRM612 & 0.67 & 2.13 & 2.03 & 0.078 & - \\
Average & 0.72 & 2.00 & 1.90 & 0.073 & - \\
Calcium carbonate & & & & & \\
LAS20 & 0.42 & 1.91 & 1.07 & 0.081 & 0.86 \\
NBS19 & 0.40 & 2.45 & 2.04 & 0.074 & 1.18 \\
TN2349 & 0.41 & 2.41 & 3.95 & 0.114 & 1.22 \\
SPA4 & 0.52 & 2.05 & 1.08 & 0.096 & 1.04 \\
Average & 0.44 & 2.21 & 2.03 & 0.092 & 1.08 \\
\hline
\end{tabular}

similar to the ${ }^{24} \mathrm{Mg} /{ }^{25} \mathrm{Ma}$ ratio. Secondary ions of ${ }^{138} \mathrm{Ba}^{+}$and ${ }^{40} \mathrm{Ca}_{2}{ }^{26} \mathrm{Mg}^{16} \mathrm{O}_{2}{ }^{+}$can only be separated at a high mass resolution of 18000 . This is well beyond the possibility of Nano-SIMS, if a useful sensitivity is to be maintained. Therefore, we corrected the interference of ${ }^{40} \mathrm{Ca}_{2}{ }^{26} \mathrm{Mg}^{16} \mathrm{O}_{2}{ }^{+}$on ${ }^{138} \mathrm{Ba}^{+}$based on the empirical relationship that the ${ }^{40} \mathrm{Ca}_{2}{ }^{24} \mathrm{Mg}^{16} \mathrm{O}_{2}{ }^{+} / 24 \mathrm{Mg}^{+}$ratio equals 0.002 in a calcium carbonate matrix, as follows:

$$
\left({ }^{138} \mathrm{Ba} /{ }^{43} \mathrm{Ca}\right)_{\text {cor }}=\left({ }^{138} \mathrm{Ba} /{ }^{43} \mathrm{Ca}\right)_{\text {obs }}-\left({ }^{26} \mathrm{Mg} /{ }^{43} \mathrm{Ca}\right)_{\text {obs }} \times 0.002,
$$

where the subscripts "cor" and "obs" denote the corrected and observed ratios. The corrected ${ }^{138} \mathrm{Ba} /{ }^{43} \mathrm{Ca}$ ratios of calcium carbonate samples are listed in the right-most column of Table 3. Figure $3 \mathrm{c}$ shows the relationship between the corrected ${ }^{138} \mathrm{Ba} /{ }^{43} \mathrm{Ca}$ ratios and the ICP-MS data together with those of the original data. A linear-regression analysis of the corrected data gives a relatively smaller slope of $0.000467 \pm 0.000043$ (1 sigma) and Y-intercept of $0.000307 \pm 0.000402$ ( 1 sigma). The Y-intercept is two-times smaller than that of the original value, suggesting that the correction works well. The corrected secondary ion yields of $\mathrm{Ba} / \mathrm{Ca}$ based on the Eq. (1) are listed in the rightmost column of Table 4 . Note that the variation is significantly reduced when compared with the original uncorrected values.

No systematic relationship appears to exist between the secondary ion yields (Table 4) and the physical characteristics of Group II elements $(\mathrm{Mg}, \mathrm{Ca}, \mathrm{Sr}$, and $\mathrm{Ba})$, such as the ionic radius and electronegativity. Based on the local thermal equilibrium (LTE) model $^{29}$ as applied to secondary ion production by ${ }^{16} \mathrm{O}^{-}$ion bombardment, the following equation ${ }^{30}$ is derived:

$$
n_{\mathrm{M}+} / n_{\mathrm{M}}=\text { const } \times\left(T^{3 / 2} / n_{\mathrm{e}_{-}}\right) \times\left(B_{\mathrm{M}_{+}} / B_{\mathrm{M}}\right) \times \exp \left(-I_{\mathrm{M}} / k T\right),
$$

where $T$ is the plasma temperature in $\mathrm{K}, n$ is the number of atoms, ions and electrons, $B$ is the partition function of the atoms or ions and $I_{\mathrm{M}}$ is the ionisation potential. If this is applicable to the present case, the relative secondary ion yields of Group II elements are probably functions of the ionization potential as follows:

$$
S_{\mathrm{A}} / S_{\mathrm{Ca}}=\text { const } \times \exp \left\{\left(I_{\mathrm{Ca}}-I_{\mathrm{A}}\right) / k T\right\},
$$

where $S$ is the secondary ion yield of Group II elements indicated by the subscript $(\mathrm{A}=\mathrm{Mg}, \mathrm{Sr}$ or $\mathrm{Ba})$. Figure 4 shows the relationship between the secondary ion yields for Group II (normalized to $\mathrm{Ca}$ ) in silicate glass and a calcium carbonate matrix and the first valence ionization potential. The relative

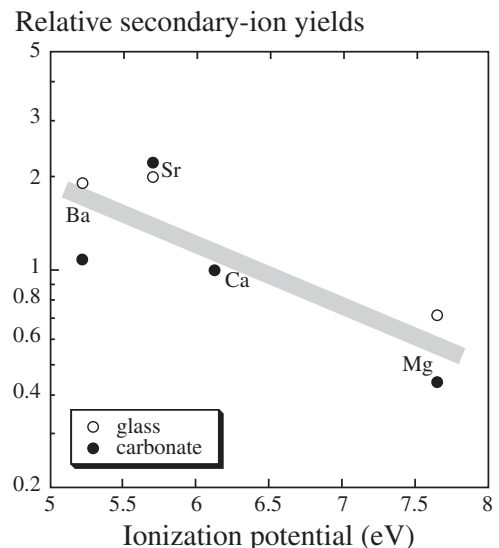

Fig. 4 Relationship between the secondary ion yields of Group II elements and the ionisation potential of the first valence. The thick line shows a trend expressed on the basis of Eq. (3).

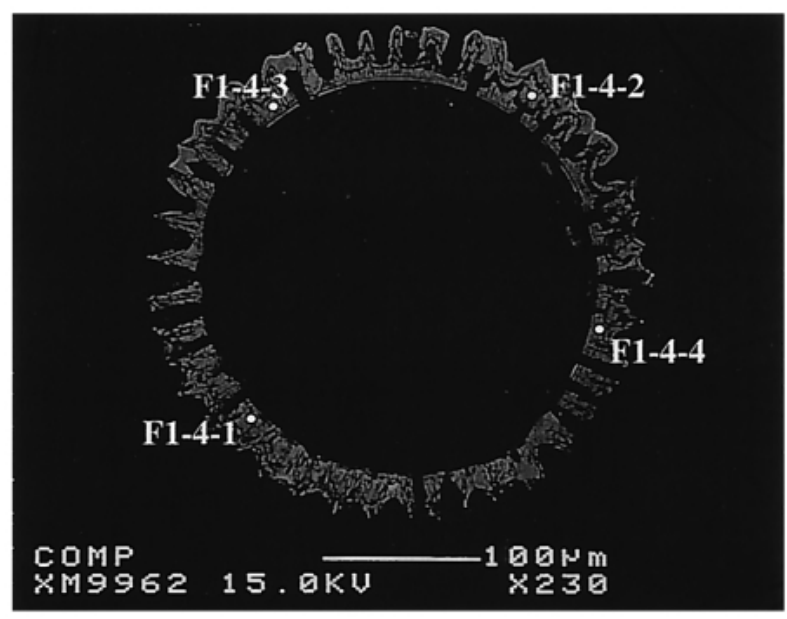

Fig. 5 Composite image of foraminifera (Globigerinoides sacculifer) taken by EMP. This sample was assigned by F1 - 4 in Table 5, together with approximate position of analyzed spots $(1-4)$ by Nano-SIMS.

secondary ion yields decrease with increasing ionization potential, even though the data are somewhat scattered. The trend illustrated by the thick line in Fig. 4 is consistent with the correlation expressed by the basis of Eq. (3). Even though the chemical compositions of silicate glasses are appreciably different from calcium carbonate, the decreasing trend with the ionization potential is similar. There may be some physical mechanism, such as the LTE model, ${ }^{29}$ which can explain the relationship observed in Fig. 4, irrespective of the chemical compositions (matrix effect).

\section{Foraminifera}

The basis for the $\mathrm{Mg} / \mathrm{Ca}$ paleothermometry method lies in laboratory experiments, showing that the partition coefficient of $\mathrm{Mg}^{2+}$ into inorganic calcite correlates strongly with temperature. ${ }^{5} \quad$ A culture study ${ }^{31}$ of the temperature-dependent uptake of $\mathrm{Mg}$ in marine biogenic calcite has confirmed this issue. The $\mathrm{Mg} / \mathrm{Ca}$ ratios of planktonic foraminifera have been used to estimate Quaternary sea surface temperatures. ${ }^{32}$ Thus, there has been increasing interest in using foraminifera $\mathrm{Mg} / \mathrm{Ca}$ as a proxy for this temperature, and an inter-laboratory 
Table 5 Minor and trace elements in foraminifera shells measured by Nano-SIMS

\begin{tabular}{lcccc}
\hline $\begin{array}{c}\text { Foraminifera } \\
\text { (G.-sac. })\end{array}$ & $\begin{array}{c}\mathrm{Mg} / \mathrm{Ca} \\
(\mathrm{mmol} / \mathrm{mol})\end{array}$ & $\begin{array}{c}\mathrm{Sr} / \mathrm{Ca} \\
(\mathrm{mmol} / \mathrm{mol})\end{array}$ & $\begin{array}{c}\mathrm{Ba} / \mathrm{Ca} \\
(\mu \mathrm{mol} / \mathrm{mol})\end{array}$ & $\begin{array}{c}\mathrm{U} / \mathrm{Ca} \\
(\mu \mathrm{mol} / \mathrm{mol})\end{array}$ \\
\hline F1-1-1 & 3.76 & 1.13 & 16.0 & 0.187 \\
F1-2-1 & 2.79 & 1.14 & 5.77 & 0.251 \\
F1-3-1 & 2.79 & 1.20 & 5.31 & 0.398 \\
F1-4-1 & 3.56 & 1.11 & 10.7 & 0.156 \\
F1-4-2 & 3.02 & 1.11 & 8.49 & 0.329 \\
F1-4-3 & 5.30 & 1.03 & 10.8 & 0.202 \\
F1-4-4 & 2.16 & 1.19 & 7.16 & 0.500 \\
Average & 3.34 & 1.13 & 9.18 & 0.289 \\
STDEV & 1.01 & 0.06 & 3.70 & 0.126 \\
\hline
\end{tabular}

calibration was recently carried out. ${ }^{33}$ Note that all of these experiments were undertaken by bulk analysis.

The ${ }^{26} \mathrm{Mg} /{ }^{43} \mathrm{Ca},{ }^{88} \mathrm{Sr} /{ }^{43} \mathrm{Ca},{ }^{138} \mathrm{Ba} /{ }^{43} \mathrm{Ca}$ and ${ }^{238} \mathrm{U}^{16} \mathrm{O}_{2} /{ }^{43} \mathrm{Ca}$ ratios of four shells of foraminifera (Globigerinoides sacculifer) were measured by using Nano-SIMS at spot sizes of 5-6 $\mathrm{m}$. Data were calibrated against those of LAS20 on the same mount. Four spot analyses were carried out on the F1-4 sample (Fig. 5), while only one spot was analyzed on the other samples. During the measurements, we selected inclusion-free and crack-free homogeneous regions. Table 5 lists the observed $\mathrm{Mg} / \mathrm{Ca}, \mathrm{Sr} / \mathrm{Ca}$, $\mathrm{Ba} / \mathrm{Ca}$ and $\mathrm{U} / \mathrm{Ca}$ ratios of the foraminifera. The precisions were estimated by the reproducibility of repeated spot analysis of LAS20, $\sim 5 \%$ for minor elements $(\mathrm{Mg}$ and $\mathrm{Sr}$ ) and $\sim 10 \%$ for trace elements ( $\mathrm{Ba}$ and $\mathrm{U}$ ) at one sigma, since the error of a single spot analysis on the actual sample (estimated by the standard deviation of 50 ratios set) is smaller than those of the standard with multiple spot analyses.

The $\mathrm{Mg} / \mathrm{Ca}$ ratios vary significantly from 2.16 to 5.30 $\mathrm{mmol} / \mathrm{mol}$, which is much larger than the analytical precision. Even in a single shell (F1 - 4), the variation is up to $\pm 38 \%$, which corresponds to a temperature variation of $\pm 4-5^{\circ} \mathrm{C}$, based on a recently published calibration equation: ${ }^{34} \mathrm{Mg} / \mathrm{Ca}=0.38 \times$ $\exp (0.090 T)$, where $T$ is the seawater temperature in ${ }^{\circ} \mathrm{C}$. On the other hand, when we take the average of all data, the mean value of 3.34 agrees with the $\mathrm{Mg} / \mathrm{Ca}$ ratio of 3.15 obtained by a conventional method on bulk basis (Sagawa, personal communication). The estimated temperatures by $\mathrm{Mg} / \mathrm{Ca}=3.34$ and/or 3.15 agree with the field observation. This may indicate that although the $\mathrm{Mg} / \mathrm{Ca}$ ratio is useful as a paleoceanographic proxy on the bulk scale, it may reflect more complex patterns at $<10 \mu \mathrm{m}$ scale, such as a biological control revealed in coral skeletons. ${ }^{14}$ In contrast, the $\mathrm{Sr} / \mathrm{Ca}$ ratios are rather constant, which may be related to the fact that the glacial-interglacial variation of planktonic foraminifera $\mathrm{Mg} / \mathrm{Ca}$ is typically on the order of $20-25 \%$, while that of $\mathrm{Sr} / \mathrm{Ca}$ is only $5-6 \% .{ }^{33}$ The mean value of all $\mathrm{Sr} / \mathrm{Ca}$ measurements, 1.13 (see Table 5), is again consistent with the bulk $\mathrm{Sr} / \mathrm{Ca}$ ratio of 1.08 (Sagawa, personal communication). The variations of trace elements ( $\mathrm{Ba} / \mathrm{Ca}$ and $\mathrm{U} / \mathrm{Ca}$ ) are at the same level as that of the $\mathrm{Mg} / \mathrm{Ca}$ ratios. There is a slight negative correlation between $\mathrm{Mg} / \mathrm{Ca}$ and $\mathrm{U} / \mathrm{Ca}(R=0.710)$, which may also be attributable to a temperature effect. However, the details are beyond the scope of this paper.

In conclusion, an analytical procedure for minor elements $(\mathrm{Mg}$ and $\mathrm{Sr}$ ) and trace elements ( $\mathrm{Ba}$ and $\mathrm{U}$ ) in natural calcium carbonates has been developed using a high lateral resolution secondary ion mass spectrometer (Nano-SIMS NS50) installed at the Ocean Research Institute, the University of Tokyo. The probe diameter is significantly smaller than that available using comparable microanalysis methods, set at 5-6 $\mu \mathrm{m}$ on the sample surface, yet the detection limit is less than $1 \mu \mathrm{mol} / \mathrm{mol}$. The observed $\mathrm{Mg} / \mathrm{Ca}, \mathrm{Sr} / \mathrm{Ca}, \mathrm{Ba} / \mathrm{Ca}$ and $\mathrm{U} / \mathrm{Ca}$ ratios of carbonate samples measured by Nano-SIMS agree with those measured by LA-ICP-MS using a larger probe, confirming their reported precision and accuracy. Foraminifera shells were analyzed by Nano-SIMS, and the averages of the $\mathrm{Mg} / \mathrm{Ca}$ and $\mathrm{Sr} / \mathrm{Ca}$ ratios are consistent with data obtained by a conventional bulk-analysis method. This procedure may be applicable to a wide range of earth and environmental studies, since the elemental ratios of biogenic carbonates provide possible paleoclimate proxies, and more generally are good indicators of the geochemical reaction and transport in many geological environments.

\section{Acknowledgements}

We are grateful to T. Sagawa for providing the foraminifera samples with bulk $\mathrm{Mg} / \mathrm{Ca}$ and $\mathrm{Sr} / \mathrm{Ca}$ data. We thank $\mathrm{M}$. Nishizawa and Y. Tsutsumi for help in preparing the samples.

\section{References}

1. M. K. Gagan, L. K. Ayliffe, J. W. Beck, J. W. Cole, E. R. M. Druffel, R. B. Dunbar, and D. P. Schrag, Quat. Sci. Rev., 2000, 19, 45.

2. C. H. Lear, H. Elderfield, and P. A. Wilson, Science, 2000, 287, 269.

3. G. R. Min, R. L. Edwards, F. W. Taylor, J. Recy, C. D. Gallup, and J. W. Beck, Geochim. Cosmochim. Acta, 1995, 59, 2025.

4. D. W. Lea, Paleoceanography, 1995, 10, 733.

5. G. Hartley and A. Mucci, Geochim. Cosmochim. Acta, 1996, 60, 315 .

6. E. J. Hendy, M. K. Gagan, C. A. Alibert, M. T. McCulloch, J. M. Lough, and P. J. Isdale, Science, 2002, 295, 1511.

7. R. J. Reeder, M. Nugent, G. M. Lamble, C. D. Tait, and D. E. Morris, Environ. Sci. Technol., 2000, 34, 638.

8. E. C. Hathorne, O. Alard, R. H. James, and N. W. Rogers, Geochem. Geophys. Geosys., 2003, 4, 8408.

9. A. L. Cohen, K. E. Owens, G. D. Layne, and N. Shimizu, Science, 2002, 296, 331.

10. C. E. Zimmerman and R. L. Nielsen, Fishery Bull., 2003, 101,712 .

11. F. Hillion, B. Daigne, F. Girard, and G. Slodzian, in "Proceedings of the $9^{\text {th }}$ SIMS conference", A. Benninghoven et al. (ed.), 1993, 254.

12. A. N. Nguyen and E. Zinner, Science, 2004, 303, 1496.

13. F. J. Stadermann, T. K. Croat, T. J. Bernatowicz, S. Amari, S. Messenger, R. M. Walker, and E. Zinner, Geochim. Cosmochim. Acta, 2005, 69, 177.

14. A. Meibom, J. Cuif, F. Hillion, B. R. Constantz, A. JuilletLeclerc, Y. Dauphin, T. Watanabe, and R. B. Dunbar, Geophys. Res. Lett., 2004, 31, L23306.

15. Y. Sano, N. Takahata, and Y. Tsutsumi, Geochim. Cosmochim. Acta, 2005, 69, A397.

16. A. Ando, T. Okai, Y. Inouchi, T. Igarashi, S. Sudo, K. Maruo, S. Itoh, and S. Terashima, Bull. Geol. Survey Jpn., 1990, 41, 27.

17. C. Spotl, M. Unterwurzacher, A. Mangini, and F. J. Longstaffe, J. Sediment. Res., 2002, 72, 793. 
18. I. Friedman, J. O’Neil, and G. Cebula, Geostandard Newsl, 1982, 6, 11.

19. N. C. Sturchio, M. R. Antonio, L. Soderholm, S. R. Sutton, and J. C. Brannon, Science, 1998, 281, 971.

20. H. Hilbrecht, "Mitteilungen aus dem Geologischen Institut der Eidgen. Technischen Hochschulue unde der Universitat Zurich, Neue Folge", 1996, No. 300, 93.

21. T. Hirata and R. W. Nesbitt, Geochim. Cosmochim. Acta, 1995, 59, 2491

22. T. Iizuka and T. Hirata, Geochem. J., 2004, 38, 229.

23. S. M. Eggins, L. P. J. Kinsley, and J. M. G. Shelley, Appl. Surf. Sci., 1998, 127, 278.

24. A. Tunheng and T. Hiraya, J. Anal. At. Spectrom., 2004, 19, 932.

25. S. D. Kelly, M. G. Newville, L. Cheng, K. M. Kemner, S. R. Sutton, P. Fenter, N. C. Sturchio, and C. Spotl, Environ. Sci. Technol., 2003, 37, 1284.

26. N. Shimizu, Earth Planet. Sci. Lett., 1978, 39, 398
27. I. M. Steele, R. L. Hervig, I. D. Hutcheon, and J. V. Smith, Amer. Mineral., 1981, 66, 526.

28. G. Slodzian, in (ed.), "Secondary Ion Mass Spectrometry (SIMS III)", A. Benninghoven et al. 1982, 115.

29. C. A. Andersen and J. R. Hinthorne, Anal. Chem., 1973, 45, 1421.

30. S. J. B. Reed, Int. J. Mass Spectr. Ion Processes, 1983, 54, 31.

31. D. W. Lea, T. A. Mashiota, and H. J. Spero, Geochim. Cosmochim. Acta, 1999, 63, 2369.

32. T. Mashiotta, D. W. Lea, and H. J. Spero, Earth Planet. Sci. Lett., 1999, 170, 417.

33. Y. Rosenthal, S. Perron-Cashman, C. H. Lear, E. Bard, and S. Barker et al., Geochem. Geophys. Geosys., 2004, 5, 1029.

34. P. Anand, H. Elderfield, and M. H. Conte, Paleoceanography, 2003, 18, 1050. 